\title{
Killer WHALE (ORCINUS ORCA) PREDATION ON A FRANCISCANA DOLPHIN (Pontoporia BLAINVILLEI) IN BRAZILIAN WATERS
}

\author{
Marcos César de Oliveira Santos ${ }^{1}$ and Denis Ferreira Netto ${ }^{2}$
}

Killer whales (Orcinus orca) have been reported as predators of at least 40 different species of fish, squid, sea turtles, sea birds, and marine mammals (Heyning and Dahlheim, 1988; Jefferson et al., 1991; Baird and Dill, 1995; Ott and Danilewicz, 1998; Secchi and Vaske Jr., 1998; Visser et al., 2000; Ford, 2002; Pitman et al., 2003; Shelden et al., 2003; Reyes and GarcíaBorboroglu, 2004; Visser, 2005). Prey species have been identified through studies of stomach contents of stranded individuals, as well as through direct observations. Based on long-term studies in the temperate eastern North Pacific, two types of killer whales are known: fish-eating, and mammal-eating specialists (Bigg et al., 1990; Barrett-Lennard et al., 1996; Ford and Ellis, 1999). In two other areas in Península Valdés, Argentina (see Lopez and Lopez, 1985), and in Possession Island, Crozet Archipelago (see Guinet, 1991), killer whale foraging and feeding near-shore allowed land-based observers to record predation of both birds and mammals. Off New Zealand, water transparency, killer whales' distribution, and foraging and feeding behavioral activities displayed in coastal waters have provided adequate conditions for investigators to document their feeding habits (see examples in Visser, 1999; Visser et al., 2000; Visser, 2005). However, in most part of the range of killer whales, information on their feeding habits is still scarce. Reduced research efforts added to difficult access to these predators in the wild may represent the main causes for the lack of information in many areas.

Killer whales have been recorded along the Brazilian coast through stranding events (e.g. Castello, 1977; Bittencourt, 1983; Geise and Borobia, 1988; Dalla Rosa, 1995; Ott and Danilewicz, 1998; Dalla Rosa et al., 2002 ${ }^{3}$ ), opportunistic sightings (e.g. Lodi and Hetzel, 1998; Siciliano et al., 1999; Dalla Rosa et al., 2002), and dedicated surveys for cetaceans (e.g., Dalla Rosa, 1995; Lodi and Hetzel, 1998; Secchi and Vaske Jr., 1998; Zerbini et al., 2004). Up to 2002, a total of 20 known strandings have been reported on the Brazilian coast, of which $16(80 \%)$ were reported on the southern coast (Dalla Rosa et al., 2002). Thus, killer whale occurrence patterns, distribution and feeding habits in Brazilian waters are still poorly known.

Based on stomach content analysis of eight stranded individuals in southern Brazil, predation had been documented on: eagle stingrays from the genus Myliobatis (Castello, 1977; Dalla Rosa, 1995; Dalla Rosa et al., 2002); franciscana dolphins, Pontoporia blainvillei (Ott and Danilewicz, 1998); salps (Iasis zonaria); several cephalopod species; weakfish (Cynoscion guatucupa); and Burmeirter's porpoises (Phocoena spinipinnis) (see Dalla Rosa, 1995; Dalla Rosa et al., 2002). A survey conducted from 1987 to 1991 with longline fisheries in southern Brazil (30S to $35^{\circ} \mathrm{S}$ ) showed that killer whales commonly attacked hooked tuna (Thunnus spp.), and swordfish (Xiphias gladius), thus reducing fishermen's profits (Dalla Rosa, 1995; Secchi and Vaske Jr., 1998). In the late 1990s, predation on manta rays, Manta birostris (Lodi and Hetzel, 1998) and on unidentified ray species (Siciliano et al., 1999) were reported along the coast of Rio de Janeiro state (21-23ㅇ), southeastern Brazil.

On 22 March 2005, one of the authors (DFN) was conducting a patrolling survey on predatory fisheries along northern Paraná coastal waters (2520'S; $\left.48^{\circ} 05^{\prime} \mathrm{W}\right)$, southern Brazil. The observer was aboard an inflatable boat with two 140hp outboard engines of the Instituto Ambiental do Paraná, known as IAP II. At around 12:15pm, while looking for unauthorized fishing boats in coastal waters, observers witnessed a small dolphin been thrown into the air on two occasions. The boat approached the area and observers witnessed a killer whale attacking a franciscana dolphin. Photographs were taken with a $35 \mathrm{~mm}$ SLR camera with a 70-200mm lens, and using 100 ISO color slide film. Based on the shape and size of the dorsal fin (Figures 1 and 2), the killer whale was an adult or large subadult male. Its total length was estimated at about 5 to $6 \mathrm{~m}$. Based on its body and rostrum size (Figures 1 and 2), the franciscana was an adult. However, it was not possible to ascertain its gender. Observers spent an hour watching the killer whale grabbing the franciscana and drowning it. While leaving the area to avoid harassing the killer whale, a small stain of blood on the water's surface was seen after a long dive of the killer whale. Neither of the individuals were seen afterwards, and presumably the franciscana was killed by the killer whale.

\footnotetext{
${ }^{1}$ Projeto Atlantis/Instituto de Biologia da Conservação. Caixa Postal 6537, Barão Geraldo, 13084-970, Campinas SP Brazil. E-mail: sotalia@gmail.com.

${ }^{2}$ Instituto Ambiental do Paraná. Correspondence Address: Rua Silveira Neto, 603, casa2, Bairro Água Verde, 80620-410, Curitiba PR Brazil. E-mail: denisfoto@terra.com.br.

${ }^{3}$ Dalla Rosa, L., Secchi, E.R., Laílson-Brito Jr., J. and Azevedo, A. (2002) A review of orcas (Orcinus orca) in Brazilian waters. Pages 46-49 in Abstracts. Fouth International Killer whale Symposium and Workshop, September 23-28, CEBC-CNRS, France.
} 


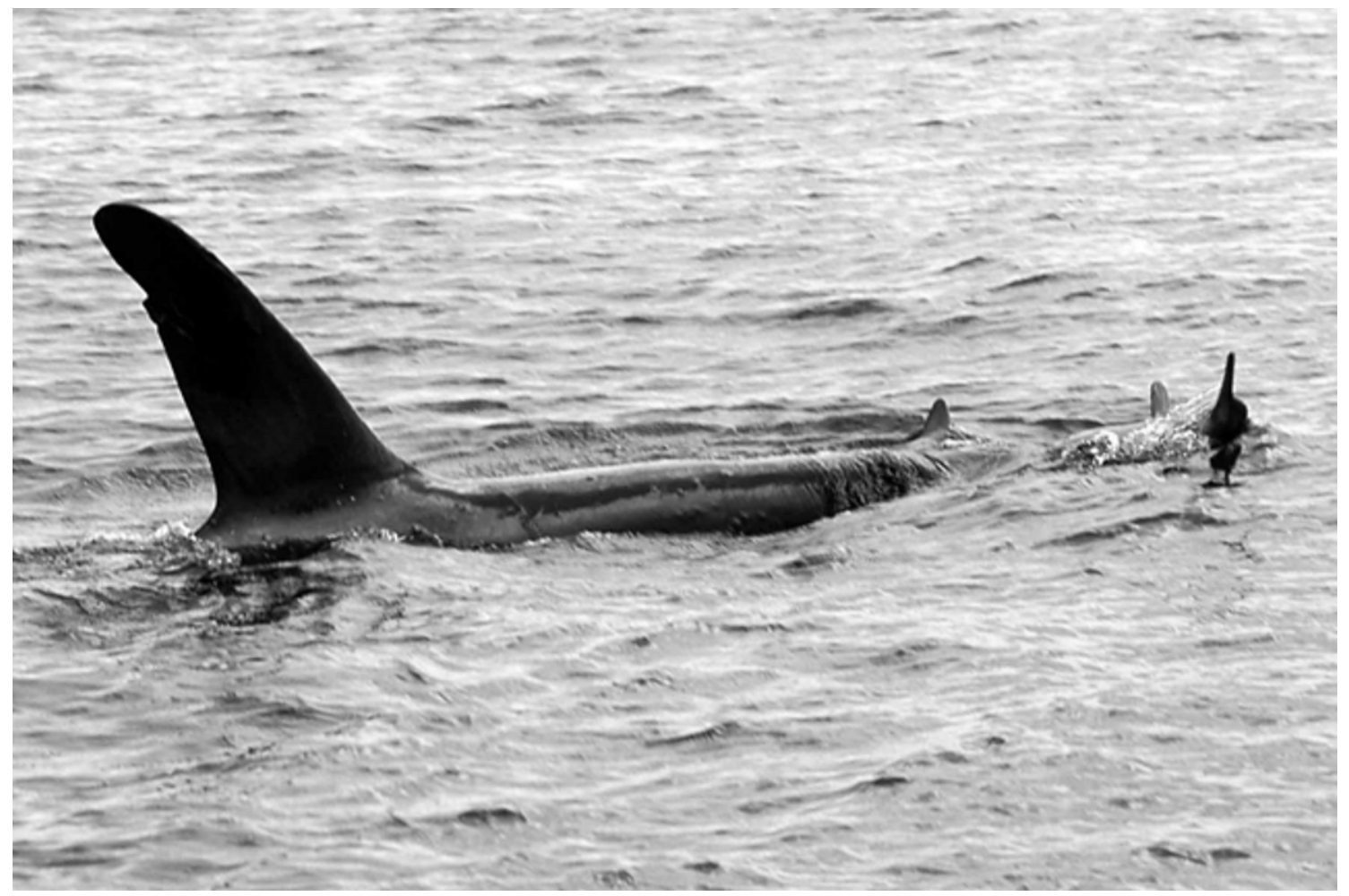

Figure 1. Male killer whale (Orcinus orca) attacking a franciscana dolphin (Pontoporia blainvillei) in Brazilian waters. Note the killer whale's large dorsal fin with two notches.

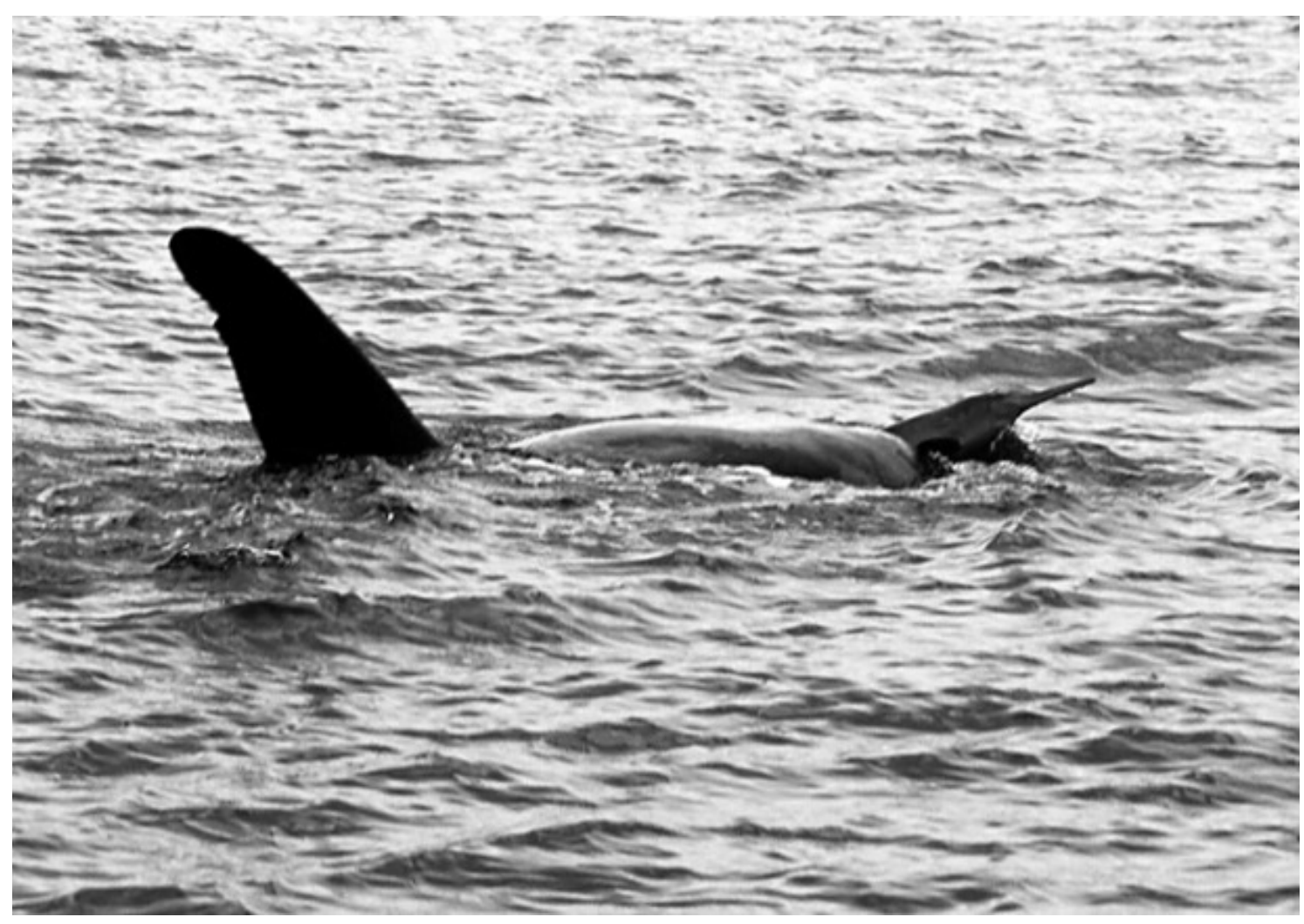

Figure 2. Male killer whale (Orcinus orca) attacking a franciscana dolphin (Pontoporia blainvillei) in Brazilian waters. Note the long-sized rostrum of the franciscana, characteristic of an adult individual. 
Killer whales are known to commonly attack marine mammals in groups (Ford, 2002). However, killer whales are also known to travel and hunt alone (see Baird and Dill, 1996). During this one-hour observation, only a male killer whale was seen attacking one franciscana dolphin, showing another evidence of a lone killer whale hunt. The attack took place in dark and shallow coastal waters about $8 \mathrm{~km}$ from the Ararapira channel, which represents the division between São Paulo and Paraná states. During the observations reported here, water depth ranged from 8 to $12 \mathrm{~m}$, as noted on the boat's echo-sounder. Killer whale sightings in southern Brazil have been commonly reported in water depths ranging from 110 to 3500m (Secchi and Vaske Jr., 1998; Zerbini et al., 2004). Along the coast of Rio de Janeiro, southeastern Brazil, sightings have been reported in shallower waters, ranging from 9 to 40m (Lodi and Hetzel, 1998; Siciliano et al., 1999). The present observation, combined with other published records, confirms the wide range of water depths in which killer whales can be found in Brazilian waters.

Onlookers mentioned the live stranding and release of a killer whale two years ago at Ilha do Mel (25⒉ $8^{\prime}$ ' ; $\left.48^{\circ} 18^{\prime} \mathrm{W}\right)$, a small island on the coast of Paraná state. Occasionally, local fishermen observed killer whales close to coastal fishing areas. Therefore, the presence of killer whales in local waters may be more common than previously thought. For the first time, a documented attack of a killer whale on a franciscana dolphin is reported. The attack took place in the Franciscana Management Area (FMA) II, sensu Secchi et al. (2003). Franciscana status in this management area has not been yet assessed due to insufficient data (Secchi and Wang, 2002). As franciscana was previously reported as a killer whale prey item in southern Brazil (Ott and Danilewicz, 1998), predation by killer whales must be considered as a potential cause of death in population viability analyses. Franciscanas have also been reported as prey of a few shark species based on stomach content analyses (e.g. Brownell, 1975; Praderi, 1985; Di Beneditto, 2004). The present observation on a killer whale attack on a franciscana, added to previous records of franciscana predation by killer whales and sharks, may be important in undestanding the population dynamics of the species in the western South Atlantic.

\section{Acknowledgements}

The authors would like to thank Robin W. Baird and Luciano Dalla Rosa and Nélio Barros for critically reviewing this manuscript, improving it with important suggestions and recommendations. We would like to thank Mr. Sebastião Carvalho, the head of the Instituto Ambiental do Paraná office in Curitiba, as well as to all the staff of Policia Florestal of Paraná. The authors would also like to thank the oceanographer Marcos B. Campolim for the first contacts on the incident to join researchers together. Marcos Santos thanks the support provided by the Cetacean Society International, the Whale \& Dolphin Conservation Society, the Earthwatch Institute and Fundação de Amparo à Pesquisa do Estado de São Paulo - FAPESP (process \#01/05128-8). Marcos Santos received grants from PROBIO (Projeto de Conservação e Utilização Sustentável da Diversidade Biológica Brasileira) - Ministério do Meio Ambiente, with the support of BIRD/GEF, and CNPq (2004 - 2005) in a governmental program directed towards the franciscana dolphin conservation.

\section{References}

BAIRD, R.W. AND DilL, L.M. (1995) Occurrence and behaviour of transient killer whales: seasonal and pod-specific variability, foraging behaviour, and prey handling. Canadian Journal of Zoology 73: 1300-1311.

BAird, R.W. AND Dill, L.M. (1996) Ecological and social determinants of group size in transient killer whales. Behavioral Ecology 7: 408-416.

Barrett-Lennard L.G., Ford, J.K.B. and Heise, K.A. (1996) The mixed blessing of echo-location: Differences in sonar use by fish-eating and mammal-eating killer whales. Animal Behavior 51: 553-565.

BigG, M.A., Olesiuk, P.F., Ellis, G.M., Ford, J.K.B. AND BALCOMB III, K.C. (1990) Social organization and geneology of resident killer whales (Orcinus orca) in the coastal waters of British Columbia and Washington State. Reports of the International Whaling Commission, Special Issue 12: 383-405.

Bittencourt, M.L. (1983) Orcinus orca "baleia assassina" (Cetacea, Delphinidae): primeiro registro para o litoral catarinense, com notas osteológicas. Arquivos de Biologia e Tecnologia 26(1): 77-103.

BrownelL, R.L. (1975) Progress report on the biology of the franciscana dolphin, Pontoporia blainvillei, in Uruguayan waters. Journal of the Fisheries Research Board of Canada 32(7): 1073-1078.

Castello, H.P. (1977) Food of a killer whale: eagle sting-ray Myliobatis found in the stomach of a stranded Orcinus orca. Scientific Reports of the Whale Research Institute 29: 107-111.

Dalla RosA, L. (1995) Interações com a pesca de espinhel e informações sobre a dieta alimentar de orca, Orcinus orca, no sul e sudeste do Brasil. Bachelor thesis, Fundação Universidade Federal do Rio Grande, Rio Grande do Sul, Brasil.

Di Beneditto, A.P.M. (2004) Presence of franciscana dolphin (Pontoporia blainvillei) remains in the stomach of a tiger shark (Galeocerdo cuvieri) captured in Southeastern Brazil. Aquatic Mammals 30(3): 311-314.

ForD, J.K.B. (2002) Killer whale Orcinus orca. Pages 669-676 in Perrin, W.F., WÜrsig, B AND Thewissen, J.G.M. (Eds) Encyclopedia of Marine Mammals. Academic Press, San Diego, California.

Ford, J.K.B. AND ELLIS, G.M. (1999) Transients: Mammal-hunting orcas of British Columbia, Washington, and Southeastern Alaska. UBC Press and University of Washington Press, Vancouver, B. C. and Seattle, WA. 
GeISE, L. ANd Borobia, M. (1988) Sobre a ocorrência de cetáceos no litoral do Estado do Rio de Janeiro, entre 1968 e 1984. Revista Brasileira de Zoologia 4(4): 341-346.

GUINET, C. (1991) Intentional stranding apprenticeship and social play in killer whales (Orcinus orca). Canadian Journal of Zoology 69: 2712-2716.

Heyning, J.E. and Dahlheim, M.E. (1988) Orcinus orca. Mammalian Species 304: 1-9.

Jefferson, T.A., Stacey, P.J. ANd BAird, R.W. (1991) A review of killer whale interactions with other marine mammals: predation and co-existence. Mammal Review 21(4): 151-180.

Lodi, L. And Hetzel, B. (1998) Orcinus orca (Cetacea; Delphinidae) em águas costeiras do Estado do Rio de Janeiro. Bioikos 12(1): 46-54.

LopeZ, J.C. AND Lopez, D. (1985) Killer whales (Orcinus orca) of Patagonia, and their behavior of intentional stranding while hunting nearshore. Journal of Mammalogy 66(1): 181-183.

Отт, P.H. AND Danilewicz, D. (1998) Presence of franciscana dolphins (Pontoporia blainvillei) in the stomach of a killer whale (Orcinus orca) stranded in southern Brazil. Mammalia 62(4): 605-609.

Pitman, R.L., O'Sullivan, S. and Mase, B. (2003) Killer whales (Orcinus orca) attack a school of pantropical spotted dolphins (Stenella attenuata) in the Gulf of Mexico. Aquatic Mammals 29(3): 321-324.

Praderi, R. (1985) Relaciones entre Pontoporia blainvillei (Mammalia: Cetacea) y tiburones (Selachii) de aguas Uruguayas. Communicaciones en Zoología del Museo de Historia Natural, Montevideo 11: 1-19.

Reyes, L.M. and García-Borboroglu, P. (2004) Killer whale (Orcinus orca) predation on sharks in Patagonia, Argentina: a first report. Aquatic Mammals 30(3): 376-379.

Secchi, E.R. ANd VASKe Jr., T. (1998) Killer whale (Orcinus orca) sightings and depredation on tuna and swordfish longline catches in southern Brazil. Aquatic Mammals 24(2): 117-122.

Secchi, E.R. And Wang, J.Y. (2002) Assessment of the conservation status of a franciscana (Pontoporia blainvillei) stock in the Franciscana Management Area III following the IUCN red list process. The Latin American Journal of Aquatic Mammals 1 (special issue 1): 183-190.

Secchi, E.R., Danilewicz, D. and Ott, P.H. (2003) Applying the phylogeographic concept to identify franciscana dolphin stocks: implications to meet management objectives. Journal of Cetacean Research and Management 5(1): 61-68.

Shelden, K.E.W., Rugh, D.J., Mahoney, B.A. and Dahlheim, M.E. (2003) Killer whale predation on belugas in Cook Inlet, Alaska: Implications for a depleted population. Marine Mammal Science 19(3): 529-544.

Siciliano, S., Laílson-Brito Jr., J. And Azevedo, A. (1999) Seasonal occurrence of killer whales (Orcinus orca) in waters of Rio de Janeiro, Brazil. Zeitschrift für Säugetierkunde (Mammalian Biology) 64(4): 251-255.

VISSER, I.N. (1999) Benthic foraging on stingrays by killer whales (Orcinus orca) in New Zealand waters. Marine Mammal Science 15(1): 220-227.

VISSER, I.N. (2005) First observations of feeding on thresher (Alopias vulpinus) and hammerhead (Sphyrna zygaena) sharks by killer whales (Orcinus orca) specialising on elasmobranch prey. Aquatic Mammals 31(1): 83-88.

Visser, I.N., Berghan, J., Van Meurs, R. and Fertl, D. (2000) Killer whale (Orcinus orca) predation on a shortfin mako shark (Isurus oxyrinchus) in New Zealand waters. Aquatic Mammals 26(3): 229-231

Zerbini, A.N., Secchi, E.R., Bassoi, M., Dalla Rosa, L., Higa, A., Sousa, L., Moreno, I.B., Möller, L.M. And CAON, G. (2004) Distribuição e abundância relativa de cetáceos na Zona Econômica Exclusiva da região sudeste-sul do Brasil. Série Documentos REVIZEE: Score Sul. 